\title{
WCZESNA POEZJA WATA I MIŁOSZA - W KRĘGU MYŚLI I SYMBOLIKI GNOSTYCKIEJ
}

\author{
BARBARA SIENKIEWICZ*
}

We wstępie do Mojego wieku pisze Miłosz: ,przed wojną Wata osobiście nie znałem. Przyjaźń nasza datowała się od pewnego wspólnie spędzonego a żałobnego sylwestra w Warszawie powojennej i umacniała się następnie wskutek spotkań podczas ich pobytu za granicą"1. Kiedy jednak Wat próbował nie z Miłoszem nagrywać „pamiętnik mówiony”, „okazało się, że brak trudnego do nazwania prądu przebiegającego między rozmówcami”, co skazało podjęte próby na niepowodzenie. Pisze Miłosz o „wspólnym gruncie”, o rozumieniu się „w pół słowa”. Wreszcie, kiedy próbuje określić ten „wspólny grunt”, stwierdza: „Bardzo ważny był fakt, że należeliśmy do tej samej konfraterni, choć on wywodził się jako formacja z lat dwudziestych, ja trzydziestych" ". Niewątpliwie chodziło o wspólne lektury, „literackie plotki i legendy”, ale przede wszystkim o pewną intelektualną formację, o - jak pisze Miłosz o Wacie - „niepospolitą inteligencję, niezwykłe oczytanie", o umysłowe wyrafinowanie ${ }^{3}$.

Obu łączą młodzieńcze sympatie lewicowe, oczywiście znacznie bardziej zaawansowane w przypadku Wata, choć i Miłosz się do nich przyznaje: „byłem nastawiony dość lewicowo [...]. Nie chcę sprawiać wrażenia, że byłem prawdziwie lewicowy w sensie fanatyzmu marksistowskiego, ale jednakże miałem te skłonności" ${ }^{4}$. Z drugiej strony płaszczyznę porozumienia buduje zainteresowanie problematyką religijną, od początku i nieustająco obecne w ich poezji, co dobrze poświadczają wypowiedzi Miłosza w rozmowie z Renatą Gorczyńską. Sympatie lewicowe i tematyka religijna - to trudna, paradoksalna koincydencja, wymagająca przeto namysłu.

* Barbara Sienkiewicz - prof. dr hab., Wydział Filologii Polskiej i Klasycznej UAM w Poznaniu.

${ }^{1}$ C. Miłos z, Przedmowa [w:] A. Wat, Mój wiek. Pamiętnik mówiony. Cz. I. Rozmowy prowadził i przedmową opatrzył. C. Miłosz. Do druku przygotowała L. Ciołkoszowa, Warszawa 1990, s. 11.

2 Ibidem, s. 16-17.

3 Ibidem, s. 9.

${ }^{4}$ E. Czarn e cka [R. Gorczyńska], Podróżny świata. Rozmowy z Czesławem Miłoszem. Komentarze, New York 1983, s. 44. 
Niewątpliwie zatem korzenie tego swoistego poczucia wspólnoty, rozwiniętej i wzmocnionej w okresie powojennym, w szczególności w czasie spisywania Mojego wieku, tkwią już w okresie przedwojennym. Analogię, z perspektywy późniejszej, buduje sam Wat w Moim wieku. Mówi mianowicie o dwóch katastrofizmach - jego pokolenia i pokolenia Miłosza, przy czym wyraźnie je różnicuje. W pierwszym wypadku należałoby jednak mówić nie tyle o katastrofizmie pokoleniowym, ile o katastrofizmie, wedle określenia Wata, „mnie podobnych”, ukształtowanym, jak przyznaje, w dużym stopniu pod wpływem lektur, wyrażającym się z jednej strony potrzebą „,całkowiej odnowy” (bliskim awangardzie powojennej, w szczególności futurystycznej), z drugiej - utratą wiary „w możliwość przyszłej europejskiej cywilizacji”. Tak rozumiane pokolenie „miało tak samo poczucie katastrofizmu” jak kolejne - rysowała się przed nimi „ogólna katastrofa epoki”, ale także „wielka niewiadoma”, która sprawiała, że katastrofa była „niesłychanie obiecująca”, że „była radość właśnie z tego, że coś tak gruntownie od podstaw się łamie, że właściwie jest miejsce na wszystko, że wszystko wolno". Tu tkwi, zdaniem Wata, podstawowa różnica pomiędzy katastrofizmem jego pokolenia a katastrofizmem pokolenia Miłosza.

Katastrofizm twojego pokolenia odbywał się już w warunkach z jednej strony stalinizmu, a z drugiej hitleryzmu. Byliście wciśnięci, zwłaszcza w Polsce, w te nożyce. Mieliście także poczucie, jeszcze może głębsze, że epoka się skończyła, świat się skończył, cywilizacja jest niemożliwa, ale jednocześnie byliście wciśnięci między potwory o olbrzymiej sile i dynamice. [...] Ale przed nami nie było tych potworów, tylko na odwrót, było walenie się, ruiny, a la longue wesołe ruiny, rozumiesz, przedmiot do wesela duchowego, bo tu można właśnie coś nowego zbudowaćs.

Z dzisiejszej perspektywy jednak, kiedy uwzględnimy charakter ówczesnej twórczości Wata, różnica ta nie rysuje się tak wyraźnie. „W szystko wolno” realizowało się głównie w sferze poetyckiej, dokładniej - tego, co dało się wyprowadzić z hasła „słowa na wolności”, a więc „rewolucji w literaturze”, tego że „słowa są rzeczą i że można z nimi robić, co się żywnie komu podoba"'. Pisze o tym Wat także w Coś niecoś o „Piecyku”. I to te nadzieje na związek „,naszej rewolucji estetycznej, literackiej” z rewolucją społeczną dokonującą się w Rosji zwrócił ich, jak wyznaje Wat, w stronę „Nowej Kultury” Hempla, w stronę komunizmu, który jawił się im ,jako wielki nihilizm, jako wielkie wałkowanie mas"7. Ciekawe, że śladów tych fascynacji nie ma w ówczesnej poezji Wata. Można je natomiast, i to liczne, odnaleźć u Miłosza w Poemacie o czasie zastygłym (1933), co zbliża wiersze tomu do poezji interwencyjnej, ,proletariackiej”, jak choćby w wierszu Przeciwko nim z podtytułem „Z powodu procesu Blachowskiego, zabójcy Gastona Koehler-Badin":

\footnotetext{
${ }^{5}$ A. Wat, Mój wiek, s. 27.

${ }^{6}$ Ibidem.

7 Ibidem, s. 29.
} 


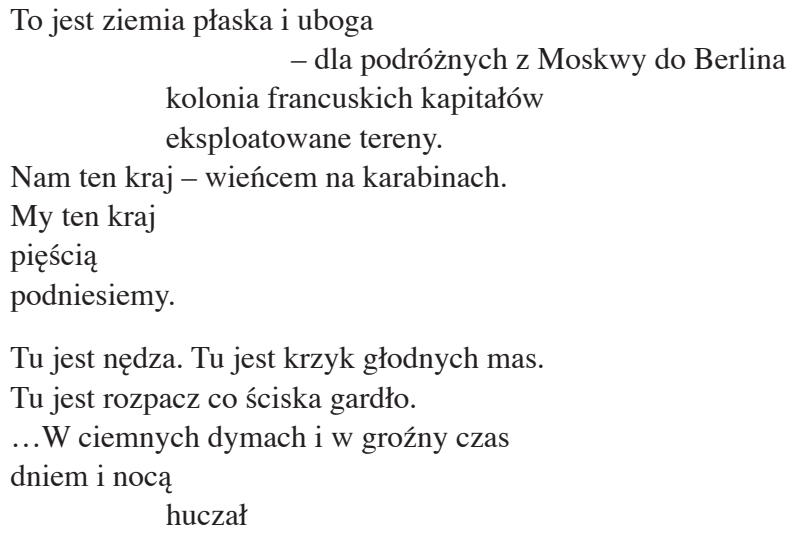

Żyrardów ${ }^{8}$.

O czasie bezpośrednio poprzedzającym wydanie Poematu mówi zresztą Miłosz: „Przeżywałem okres jakiegoś niżu. 1932 - to był okres lewicowych nieokreślonych ciągot. Dziwne środowisko... Wtedy poznałem Jana Śpiewaka, Minorskiego - wiecznego studenta i zapalonego komunistę, Gotlieba, Buksbauma"9. Raz po raz jednak w tomie obrazy nędzy, walki robotników, cierpienia więźniów zamkniętych w celach, zderzanego z obrazami kapitalistów palących holenderskie cygara czy państwowych świąt kontrastowanych z działaniami sekwestratorów, którzy spisują krowy, uzupełniają wizje kosmicznych katastrof, jak w wierszu II z cyklu Lqd (wizje) ${ }^{10}$. I te zaczną dominować w tomie kolejnym, Trzy zimy, zaniknie natomiast tematyka społeczna, proletariacka; może z wyjątkiem frazy z wiersza $O$ ksiqżce: „My niespokojni, ślepi i epoce wierni, / gdzieś daleko idziemy, nad nami październik / szumi liściem, jak tamten łopotał sztandarem" "11 którą można odczytać jako aprobatywną wobec dzieła „października”, ale można też widzieć w niej gest przezwyciężenia wcześniejszej fascynacji ${ }^{12}$.

„Zakwestionowanie europejskiej cywilizacji”, przeświadczenie, że dotarła do stanu głębokiego kryzysu czy nawet wyczerpania, kieruje zatem obu poetów w stronę lewicowych poszukiwań, ale też religijnych. I w tym drugim wypadku jest to zwrot, jak powiada Venclova o Wacie, w znacznym stopniu obrazoburczy ${ }^{13}$.

${ }^{8}$ C. Miłos z, Przeciwko nim [w:] Poemat o czasie zastygłym, Wilno 1933, s. 7.

${ }^{9}$ E. Czarnecka, op. cit., s. 30.

${ }^{10}$ C. Miłos z, Lqd (wizje). II [w:] Poemat o czasie zastygłym, s. 15-16.

${ }^{11}$ C. Miłosz, O ksiqżce [w:] Poezje, Warszawa 1988, s. 20. Dalej wiersze Miłosza cytuję wedle tego wydania; po cytacie podaję numer strony.

${ }^{12}$ Co sprawiło, jak wspomina Miłosz, iż krytycy związani z lewicą chłodno przyjęli Trzy zimy: „u Zagórskiego, u mnie, jest jakaś nieokreślona katastrofa, kiedy chodzi przecież o konkretną, o polityczną" - E. C zarneck a, op. cit., s. 40.

${ }^{13}$ T. Ven clova, Aleksander Wat - obrazoburca. Przeł. J. Goślicki, Kraków 1997 oraz Gnostyczny „Piecyk” Aleksandra Wata, „Teksty Drugie” 1994, z. 2. Tu pisze: „Ta rozpiętość rejestrów - od rozpaczliwego do «rozbawionego» obrazoburstwa - stanowi właśnie o oryginalności i wyrazistości Mopsożelaznego piecyka" (s. 59). 
Czy wszakże obrazoburstwo obu da się wywieść z lewicowego światopoglądu? Takie rozwiązanie wydaje się pozorne. Obecność motywów ciemności, snu, kosmiczne wizje wskazują bowiem, że już na etapie Poematu o czasie zastygłym w perspektywie Miłosza pojawiły się niepokojące kwestie, których nie rozwiązywał klucz lewicowy. Okazał się on niewystarczający, niezdolny do rozwiązania istotnych, głębszych problemów: obecności zła w świecie, cierpienia, perspektywy nicości, kryzysu kultury i cywilizacji nowoczesnej, które objawiły swoją indolencję, nie zlikwidowały zła, odwrotnie - obnażyły je, pogłębiły bowiem alienację człowieka. One też zapewne w przypadku Wata podsuwały takie obrazy, jak w wierszu Wieś ${ }^{14}$, obrazy, które nijak nie sugerują „wesela duchowego" i „radosnego” katastrofizmu w przeciwieństwie do „ciemnego”, charakteryzującego pokolenie Miłosza. Niepokojąca wizja w tym wierszu niewątpliwie pokrewna jest ze względu na charakter i motywy o dekadę późniejszym, Miłoszowym. W istocie zatem mówić należałoby o jednym katastrofizmie, a raczej wspólnym źródle katastrofizmu i katastroficznych wizji, jakiekolwiek formy by przybierał. Katastrofizm radykalnie oddala od lewicowego programu, toteż u obu następuje odwrót od niego, co stanowi wspólny rys biografii. Ciekawa w tej perspektywie okazuje się droga Hempla, redaktora komunistycznej „Nowej Kultury”, wspominana przez Wata w rozmowie z Miłoszem:

Hempel był już u komunistów. Hempel to znowu bardzo ciekawa formacja polska. Rodzina: jakiś bratanek - ambasador w Japonii, on sam związany bardzo z piłsudczykami dawno, kiedyś we wczesnej młodości. Poszukiwacz Boga, teozof, zaczął od tego, że pisał teozoficzne wiersze i założył Towarzystwo Teozoficzne, takie grono osób, które zamieszkały w Zakopanem i co rano, o wschodzie słońca, na jakiejś górze modliły się do słońca ${ }^{15}$.

Droga od teozofii do komunizmu, czy odwrotnie, nie okazuje się zbyt długa. Podobnie, choć nie teozofia okazała się alternatywą, było zarówno w przypadku Wata, jak Miłosza. Obaj, choć w różnych momentach dziejowych, odczuwali to samo przesilenie kultury i cywilizacji europejskiej. Jak mówi Miłosz: „Chodziło o koniec pewnego świata. Można powiedzieć, że świat się systematycznie kończy. Jakkolwiek to nazwiemy, to, poza wszystkimi pozorami, głównym powodem polskiego katastrofizmu była świadomość kończenia się pewnej fazy historycznej" ${ }^{\prime 16}$. Wedle obu wyczerpały się też możliwości odpowiedzi, jakich dotąd udzielała ta kultura. To kazało im szukać gdzie indziej - zwrócić się w stronę myśli gnostyckiej, a motywów budujących wizję katastrofy szukać w bogatym rezerwuarze gnostyckiej symboliki. O Trzech zimach w rozmowie z Gorczyńską mówi Miłosz:

${ }^{14}$ A. Wat, Wieś [w:] Poezje zebrane, w opracowaniu A. Micińskiej i J. Zielińskiego, Kraków 1992, s. 158-159. Dalej wiersze Wata cytuję wedle tego wydania; po cytacie podaję numer strony.

${ }^{15}$ A. Wat, Mój wiek, s. 30.

16 E. Czarnecka, op. cit., s. 43. 
Myślę, że tu uporanie się z moimi dramatami młodzieńczymi osiągnęło lepszy wyraz, bo na o wiele głębszym poziomie. [...] Pieśń na przykład jest wierszem w dużym stopniu ekstatycznym. Równocześnie jest to wiersz w pewnym sensie manichejski, bo kobieta, która tam występuje, jest związana z ziemią, stąd wielka pochwała ziemi, ale zarazem i gorycz ziemi. [...] Gdy pisałem Pieśn, to namiętnie czytałem Wyznania świętego Augustyna ${ }^{17}$.

Lektura Wyznań Augustyna, w początkowym etapie duchowej drogi - manichejczyka, nie dziwi. I ten kierunek poszukiwań był ważniejszy niż afiliacja do ruchów awangardowo-rewolucyjnych, lewicowych. Wiązał się z potrzebą sięgnięcia po symbolikę inną niż katolicka, taką, w której centrum sytuuje się problem zła metafizycznego, należącego do natury świata. W tym kontekście lokować należy „obrazoburstwo”, niewątpliwie silniejsze w poezji Wata, jak choćby w wierszu o incipicie „Śpiewały chórem obłoki...”:

Gdy naraz ucichły chmury, umilkły gorące wichry,

i krzyknął na krzyżu rozpięty, przybity do krzyża Antychryst:

- Lucyfer! Lucyfer! - wołał, i nikt się nie odezwał,

wyciągał ręce bezsilnie, jak polska płacząca wierzba (s. 165).

Pokrewne, „obrazoburcze” wizje pojawiają się również u Miłosza. W Powolnej rzece czytamy:

Na wydmach Maria, śpiewali, Maryja, rękę zbroczoną składając na siodło, nie wiedział, czy to jest to nowe godło, które ma zbawiać, chociaż dziś zabija (s. 28).

Na świętokradcze „odwracanie” obrazu Madonny w Piecyku Wata zwraca uwagę Venclova ${ }^{18}$, a o debiutanckim poemacie pisze, iż jego „religijny wymiar [...] jest dość oczywisty”, cały zaś poemat „mógłby uchodzić za popis bluźnierstwa"19. Perspektywa oceny zmienia się jednak, jeśli uwzględnimy, iż oba zacytowane wiersze nawiązują do gnostyckiej interpretacji roli Jezusa, osadzone są zatem w innej niż chrześcijańska tradycji.

Spór tych dwu tradycji: katolicko-chrześcijańskiej i gnostyckiej wpisany został w wiersz Miłosza Do księdza Ch. Ksiądz Ch., zgięty „nad smutnymi ołtarzami Pana”, „długo uczył pogardy wszystkiego prócz zgonu”. Jest on tu zatem reprezentantem Boga starotestamentowego, surowego, karzącego, ale też pewnego ascetyzmu wpisanego w chrześcijaństwo. Jego fanatyzm - „nienawiścią paliłeś, aż sczerniałe głownie / spadły w noc, a noc była dla ciebie kościołem" (s. 32) - budził, jak wyznaje podmiot wiersza, w przeszłości opór. Dziś, choć pod-

17 Ibidem, s. 23.

${ }^{18}$ T. Ve n clova, Gnostyczny „Piecyk” Aleksandra Wata, s. 66.

${ }^{19}$ Ibidem, s. 61. 
miot występuje z innej perspektywy wyjściowej - gnostycznego „ognia świata”, rysuje się pewna płaszczyzna porozumienia. Wspólnotę buduje wizja zbliżającej się apokalipsy, jak i pogarda dla świata, łudzącego pięknem - „dziś ja, uczeń, poznałem nicość form powabnych". Pokrewna okazuje się także abominacja wobec cielesności człowieka, choć w tej sferze rysują się zarazem pewne różnice. Podmiot bowiem cielesność wiąże z materią i uosabiającymi ją „mocami”, nie od niego zależnymi, demiurgicznymi - ,dojrzałem, moje ciało jest czułą kołyską / dla mocy, w których płaczu zawiera się wszystko, leżą w pięknym posłaniu i miłość, i głód”. Także charakter wizji apokaliptycznej, zarysowanej przez podmiot, niewiele ma wspólnego z Sądem Ostatecznym, źródłem zagłady okazuje się bowiem „morze nicości”. Element polemiczny wobec nauk Księdza Ch., wywiedzionych z tradycji biblijnej, zawiera także zapowiedź, iż chrzest ostatnich pogan dokona się w czeluścich ziemi (,Ziemia usta rozewrze, w jej dudniącej katedrze / chrzest odbiorą ostatni poganie), co niewątpliwie jest źródłem przeświadczenia o symbolicznej ,martwocie” wszystkiego, co „poczęte” z „głębi” ziemi, jak w wierszu Ptaki:

Wszystko, co z twojej głębi może być poczęte, nim granice narodzin przejdzie, martwe jest. Wszystko, czego dotykasz w nocy fundamentach, sypie się jak igliwia jesiennego deszcz (s. 8).

Narodziny bowiem, wejście w ciało (nie przypadkiem w rozmowie z Gorczyńską wspomina Miłosz Platona), skazuje każde istnienie na pozostawanie w sferze śmierci, martwoty, nocy, co trudno uzgodnić z chrześcijańską wizją świata. O Hymnie mówi Miłosz, iż jest oparty na sprzecznościach:

To jest u mnie trwałe: z jednej strony skłonność do ekstazy, zjednoczenia się ze światem rzeczy [...] z równoczesnym zgryzem negatywnym [...]. Hymn nie jest o wyłączeniu ze świata, ale można byłoby się pokusić o zestawienie go z wierszem napisanym kilka lat później, z wierszem absolutnie w tradycji gnostycznej, to jest z Wcieleniem, gdzie jest już zupełne przeciwstawienie ja - oni, ludzie - świat, tak jak w Hymnie o perle. We Wcieleniu cała ziemia, czyli ówczesna Warszawa, gdzie ten wiersz napisałem bodaj w 1937 roku, ukazuje się jako ten Egipt z Hymnu o perle i jest wielką tęsknotą do zbawienia, aż do jakiejś intuicji ukrzyżowania czy chęci ukrzyżowania ${ }^{20}$.

Zestawiając dalej te dwa wiersze, konkluduje Miłosz: „Albo jest nacisk na oddzielenie się i na zbawienie (elementy platońskie i manichejskie nie są tak odległe, u Platona dualizm był bardzo silny), albo jest nacisk na zespolenie z przemianą, z ruchem. Łącznie z ekstazą umierania"21. Ten dualizm, właściwy tradycji gnostycznej: Boga i Stwórcy, Światła i Ciemności, dobra i zła, prawdziwego życia i snu, przenika poezję Miłosza z tego okresu.

${ }^{20}$ E. Czarnecka, op. cit., s. 27.

${ }^{21}$ Ibidem. 
W rozmowie z Gorczyńską Miłosz mówi: „w mojej twórczości jest bardzo silne wyczekiwanie nowej ery. [...] Trzecia Epoka Ducha, eschatologiczna"22. Komentuje Miłosz w ten sposób frazę z wiersza Powolna rzeka: „Po trzykroć muszą zwyciężyć kłamliwi, / zanim się prawda wielka nie ożywi, / i staną w blasku jakiejś jednej chwili / wiosna i niebo, i morza, i ziemie" (s. 28). Nawiązuje tu Miłosz wprost do gnostyckiej eschatologii. To właśnie doktryna manichejska mówi o Trzech Czasach: „Fundamentem nauki Maniego jest nieskończoność zasad pierwotnych, część środkowa dotyczy ich zmieszania; koniec zaś rozdzielenia Światła i Ciemności" "23, zwycięstwa Światła przeto, Żyjącego Ducha, zwycięstwa polegającego na oczyszczeniu wszelkich stworzeń skażonych ciemnością, oddzielenia w nich światła od ciemności i powrotu tych rozproszonych w świecie cząstek światła „do królestwa Światłości na końcu świata”24. Nastąpi wtedy ponowne rozdzielenie tego, co zostało zmieszane, a dokona się to w nadciągającym spoza kosmosu „,wielkim ogniu”, który nie przestanie płonąć, „dopóki wszelkie pozostałe w stworzeniu Światło nie będzie uwolnione"25.

„Wielki ogień” to jeden z podstawowych punktów sporu w wierszu Do księ$d z a C h$. Adresat wiersza właśnie temu „ogniowi świata” zaprzeczał, tymczasem w perspektywie podmiotu wiersza staje się on zapowiedzią nadejścia Trzeciego Czasu, najpełniej bodaj rozwiniętą w Ptakach i budowaną przy użyciu kluczowej gnostyckiej symboliki: „wielkiego ognia”, „wrącego” morza i przeciwstawianej mu ,wody żywej”, snu i przebudzenia:

\footnotetext{
Niech się wypełni wreszcie południe pogardy.

Pianą białą wre morze, twoje nogi liże,

słyszysz, słyszysz, jak woła: Snu zdobywco, tobie

laurem ni winem głowy martwej nie ozdobię,

niech się wypełni wreszcie południe pogardy.

Jakby minęły lata i zakwitły krzyże,

kłębi się przemieniony ogień czworga nieb (s. 9).
}

Przed „przebudzeniem” ludzie i cała natura pozostają w sferze snu, martwoty, co jawi się jako efekt związku z materią, z pięknem świata, z jego doznawaniem (miłością, głodem). Nastanie „roku odnowień” sprawia przeto, że „pragnienie, sen i miłość odtąd nic nie waży”, a „dźwięk przerażeń śpiące ziemie budzi”. Wtedy też - i to powracająca figura w wierszach Trzech zim - „Schodzi uczeń marzenia na północne kraje, / [...] przewiązał gałąź wiśni i chce wody żywej / szukać w jeziorze” (s. 7). „Woda żywa" sytuuje się tu w opozycji do morza „wrącego" białą pianą, które, w szczególności wzburzone, mętne, w symbolice gnostyckiej

\footnotetext{
${ }^{22}$ Ibidem, s. 37.

${ }^{23}$ H. J o n a s, Religia gnozy, przeł. M. Klimowicz, wyd. PLATAN 1994, s. 223.

${ }^{24}$ Ibidem, s. 237.

${ }^{25}$ Ibidem, s. 248.
} 
oznacza „,wodę Otchłani” lub Chaosu - ,pierwotne tworzywo świata ciemności, z którym zmieszała się woda żywa"26.

Motyw „ciemnych wód” pojawia się także w Pieśni. Tu ziemia, ,pączki kasztanów, światła lekkiej brzozy", umęczeni ludzie oddalają się od brzegu w stronę - co znaczące - nocy (,ze słońcem kołysanym jak flaga biegniecie w stronę nocy", s. 10). Wedle doktryny manichejskiej dwie przeciwstawne siły determinują kosmos, wszystkie rzeczy stworzone, w tym także człowieka. Ich natura, wewnętrzna konstytucja pozostają więc dwoiste jako należące do obu sfer: Światłości i Ciemności. Walka tych dwóch sił kosmicznych toczy się przeto i na obszarze wszechświata, i w człowieku. Pod względem ,zasad ostatecznych” - pisze Jonas - pochodzenie człowieka ,jest dwojakie: światowe i pozaświatowe. [...] Poprzez swoje ciało i duszę człowiek jest częścią świata [...]. W głębi duszy ukryty jest duch, albo «pneuma» [...] drobina duchowej substancji spoza świata, która pogrążyła się w świecie. Archonci stworzyli człowieka wyraźnie w tym celu, by ją tam uwięzić"27. Chór, podsuwając Annie idylliczne obrazy, niewątpliwie kusi ją, zachęca do pozostania w związku z ziemią, a zatem także z Ciemnością: „Radość wszelka jest z ziemi, nie masz prócz ziemi wesela, / człowiek jest dany ziemi, niech ziemi tylko pożąda". Anna zresztą odczytuje te słowa właśnie jako kuszenie: „Nie chcę ciebie, nie skusisz mnie. [...] / Noce miłosne z tobą gorzkie jak popiół chmur”. Zwraca się przeto do Boga: „Od ziemi ust chciwych odłącz mnie. / Od pieśni jej nieprawdziwych oczyść mnie". Oczyszczenie jednak nie jest możliwe, bowiem Anna poprzez ciało należy do świata - nie ma w niej jednego nawet „,ziarna bez rdzy”, jednego ziarna, „które by przetrwało”. Gdyby tak było,

\author{
Spokojnie czekałabym, aż zgaśnie ruch powolny, \\ a rzeczywiste nagle się obnaży \\ [...] \\ Wtedy już oni, żyjący kłamliwie \\ jak wodorosty na dnie wód zatoki, \\ byliby tym, czym leśne igliwie \\ dla kogoś, kto w las patrzy z góry, przez obłoki (s. 11).
}

„Rzeczywiste” to gnostycka prawda, niedostępna wszystkim tym, którzy żyją „kłamliwie”. Wyzwolenie świetlistej, duchowej cząstki człowieka z więzienia ciała, przebudzenie ze snu, zmartwychwstanie „duchowe”, jeszcze nie nastąpiło. Dwoista natura skazuje Annę na bytowanie w obszarze sił Ciemności, symbolizowanych przez ,ciemne wody”, ,,bieg ciemnych fal”, „czarne łąki świata”. Pozostaje ona we władzy powszechnego, nieodwracalnego losu, którego znakiem okazuje się wiatr oraz pyłek dmuchawca „na czarnych łąkach świata”.

W cytowanym fragmencie rozmowy z Gorczyńską Miłosz wskazuje manichejski trop w tym wierszu, aczkolwiek wiąże go przede wszystkim z kreacją

${ }^{26}$ Ibidem, s. 113.

${ }^{27}$ Ibidem, s. 70. 
Anny jako wzoru kobiety nieuchronnie związanej z ziemią, a zatem z materią. Ten pierwotny związek kobiety z ziemią wyeksponowany jest także w wierszu o incipicie „Ty silna noc...”. O tym wątku doktryny manichejskiej pisze Rudolph: „Werdykt o widzialnym świecie ziemskim implikuje na płaszczyźnie antropologicznej negatywną ocenę bytu cielesno-psychicznego", stanowiącego demiurgiczną, ,przeciwboską, opanowaną przez złe siły sferę, widoczną i czynną w postaci namiętności i żądz" "28. Według manichejczyków to właśnie kobieta, której prawzorem jest Ewa, związana z ciałem, namiętnościami i żądzami, odpowiada za prokreację, ta zaś ,,w strategii Szatana była wynalazkiem najbardziej niebezpiecznym” - przedłużała „,w nieskończoność niewolę Światłości”29.

O kwestionowaniu ,tradycyjnego religijnego symbolizmu i symboliki kobiecości” w Mopsożelaznym piecyku Wata pisze Venclova i odnosi je do ,gnostycznego mitu Sophii”, gdzie Sophia ,traci związek z pierwotną Jednością (pleroma) i zostaje uwięziona w świecie materii, dysharmonii i grzechu"30. Znaczący w tej perspektywie okazuje się także wiersz Wata Płodzeńe, w którym widzieć należy futurystyczną prowokację, apoteozę siły życia wyrażającej się w rozrodczości, zarazem trudno nie dostrzec, że afirmacja ta łączy się ze wstrętem i negacją: ,w sromie dwuspalnych sodom / w żywoće powstanie salon. / W salońe tym będą poczwary śedźały / pszes dźewięć hutnych mieśęcy / a potem wyjdą i będą śę śmiały / karmiąc śę mlekiem, jak święci” (s. 153-154)31. Rozrodczości poświęca Wat także drugi wiersz, Płodność. I tu - zdawałoby się - pochwała niemal niezauważalnie przechodzi w negację, której nośnikani są motywy czerni, zmierzchu, smoły, wieży Babel, ,religii ziemi”. Wezwanie: „Wypełnijmy rodzącymi ludzkimi ciałami - / religią ziemi - wszystkie miejsca przestrzeni i gwiazd!", w zakończeniu wiersza dopełnia niepokojący obraz: „tysiączne pokolenia - byki jak moloch / [...] / na drogach kolorowych padną im do kolan / anioły i bogi w szatach barwionych zmierzchem" (s. 155-156). Jakby futurystyczne prowokacje przełamywały się w głębiej zakodowanych gnostycznych wyobrażeniach.

Szczególnie wyraźne okazuje się to w wierszu Miliard kilowatów. Śpiew Adamów $i$ Ew. Futurystyczny pierwszy człon tytułu jest mylący, wiersz bowiem odsyła do gnostyckiej mitologii, wedle której stworzenie Adama i Ewy staje się przypieczętowaniem ludzkiej kondycji, co wyraża drugi człon tytułu - „Śpiew Adamów i Ew”; „Adamowie” i „Ewy” są tu ujmowani jako spadkobiercy pierwszych ludzi, kontynuujący ich antropologiczny wzór i los. Stąd liczba mnoga - zbiorowy podmiot „,śpiewu”, będący ekspresją wspólnej kondy-

${ }^{28}$ K. R u dolp h, Gnoza, przeł. G. Sowiński, Kraków 2003, s. 93-94.

${ }^{29}$ H. Jo nas, op. cit., s. 242.

${ }^{30}$ T. Ve n clov a, Gnostyczny „Piecyk” Aleksandra Wata, s. 67.

${ }^{31}$ Wiersz ten notabene Venclova zestawia z Piecykiem ze względu na wspólny obu motyw androgyne, należący „,do najbardziej fundamentalnych pojęć myśli gnostycznej, według której Bóg jest jednością bez początku i końca, przeto nie sposób odróżnić w Nim męskości od kobiecości" - ibidem, s. 71. 
cji i przeznaczenia. Los ten determinują, jak dla gnostyków, siły Zła, sprawiające, że cały świat jawi się jako „system opresji, który w konsekwencji można opisać słowami «ciemność», «śmierć», «oszustwo», «nikczemność»"32. Toteż kondycją Watowych „Adamów” i „Ew” okazuje się podleganie przemożnym mocom żywiołów (wichry, grzmocące ogonami rekiny, „Czarna ulewa”, burze, grzmoty, lewiatany), ugasanie w mroku, nieustający lęk, ,zdzieranie” miraży i fantazmatów, i w efekcie odsłanianie się właściwego wymiaru wspólnego losu - życia-ku-śmierci.

W Śpiewie sens losu „Adamów” i „Ew” wyraża rozbudowany obraz płynięcia po wzburzonym morzu, gnostycznym symbolu, powracającym także, jak wskazywałam, w większości wierszy Miłosza z Trzech zim, pod nieobecność zatem „wody żywej”:

Lśniącymi skrzydłami przerzynając powietrze,

nad morzem latający unosił się bóg,

i cisza w krąg za nim jak gdyby po wietrze

trąbiła w skręcony i ognisty róg.

Wszystkie twory wyłaziły z elementów i żywiołów,

z fal frunęły lewiatany i morskie psy.

I pośród lamentów mordowanych aniołów

Bóg rozlewał komuś ofiarę krwi (s. 161).

Bogu towarzyszą tu znaczące atrybuty: trąbienie ,skręconego i ognistego rogu”, lewiatany, ,morskie psy”, sugerujące, iż mamy do czynienia z gnostyckim Demiurgiem. Występuje on w wierszu właśnie jako twórca świata, a jego „twory” poczynają się, jak w mitologii gnostyckiej, z „elementów i żywiołów” (a nie ze „słowa”, które „było na początku”). Dowodzi tego także ostatnia fraza zacytowanego fragmentu, dotycząca zapewne Jezusa-człowieka, zrównanego zatem kondycją i cierpieniem z ludźmi, powtarzającego w tym aspekcie ich antropologiczny wzór.

Do zastanowienia zmusza w tym wierszu także motyw łudzących barwami „pararajskich zórz”. Wedle wielu gnostyckich opowieści Adam zostaje uwięziony w grobie z ciała, po czym Demiurg przenosi go do ,raju, który jednak zapewnia tylko «złudną rozkosz»”, bowiem archontów ,drzewo zostało zasadzone jako «drzewo życia». [...] «Życie», którego ma udzielać owo drzewo jest «duchem imitacji» czy też «duchem fałszu», który chce odwrócić Adama od światła, «aby nie poznał swego spełnienia»"33. Z żebra Adama tworzy odpowiednią dlań ziemska Ewę. Adam odkrywa w niej swoją istotę i dzięki drzewu uczy się poznania. Reakcja Demiurga „na odwrócenie się odeń jego stworzeń polega na wyklęciu

\footnotetext{
${ }^{32}$ K. Rudolph,op. cit., s. 75.
}

${ }^{33}$ Ibidem, op. cit., s. 115-116. 
ich i wypędzeniu z raju w «mrok»"34. I analogiczna opowieść, jak się zdaje, inspirowała wiersz Wata ${ }^{35}$.

I dla Wata, i dla Miłosza człowiek od początku, od indywidualnych narodzin, ale także od początku ludzkości, okazuje się skażony, pozostaje bowiem we władaniu sił Ciemności, nadto jest nie tylko przedmiotem ich działania, ale i podmiotem, narzędziem w rękach Ciemności. Przeświadczenie takie wpisane jest we frazę z Powolnej rzeki: ,Więc czemu twoje / oczy zamknęły w sobie blask nieczysty / jak oczy stworzeń, które nie zaznały / zła i za zbrodnią tylko tęsknią? Czemu / przez powieki zmrużone prześwieca gorąca / toń nienawiści?" (s. 2627). Rozpoznanie to potwierdza komentarz Miłosza do frazy z Bram arsenału, „A jeśli dziecko zrodzi się z tej krwi słowiańskiej”: „Jest to jakaś obsesja własnego skażenia, bardzo silna u mnie”. Gorczyńska dopowiada: „Byłby to ten sam motyw co w cyklu Osobny zeszyt - Gwiazda Piołun? Człowiek obciążony złymi genami?”. I Miłosz: „,Tak, naturalnie. To zresztą być może łączy mnie z manichejczykami, w tym sensie, że oni byli przeciwko prokreacji dlatego, że świat jest zły. A ja myślę, że i świat jest zły i że być może jestem jakoś napiętnowany"36. Prokreacja zresztą w strofie Bram arsenału poprzedzającej komentowaną frazę przedstawiona jest w zdecydowanie negatywnym świetle:

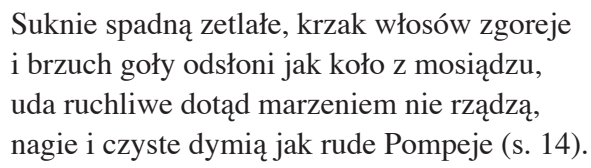

Przeświadczenie o skażeniu natury ludzkiej prowadzi u Miłosza, jak u gnostyków, do eksponowania motywu winy i kary, jak w Dialogu, gdzie kara spotyka tych, którzy przywiązani są do materialności świata, ulegają jego pokusom, do jakich zalicza się także sztuka, jako przynależna do sfery światowej (,wiedząc, że słuszna nastąpiła kara / za młodość bujną, sztukę wiarołomną"). Winą człowieka jest przeto pycha, pożądanie, okrucieństwo, bezrefleksyjne pozostawanie w sferze snu, martwoty, a zatem niedociekanie prawdy, niepodejmowanie wysiłku przebudzenia do życia. Tak ujmuje to Miłosz w Obłokach:

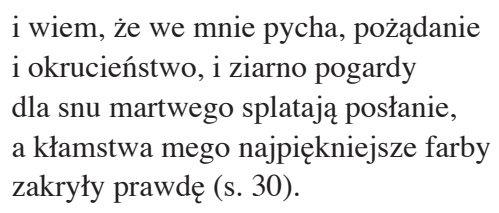

34 Ibidem, s. 116.

35 Być może inspirowała także mizoginiczny, choć nieco żartobliwie, wiersz Stare konie, w którym siłę demiurgiczną uosabiałby „możny sułtan”.

36 E. Czarnecka, op. cit., s. 29. 
Na przeciwstawieniu kłamstwa, snu, martwoty, złudnych uroków świata i prawdy, przebudzenia, życia zbudowany jest też wiersz Dialog. Przewodnik prezentuje tu kolejne obrazy, dowodzące przywiązania Ucznia do zmysłowego kształtu świata, i zadaje istotne pytanie: „A w ręce zżartej snami ziemskiemi / co trzymasz? berło? / Czy tylko świecę, błyszczącą podziemi / martwym materiom?" (s. 25). Ukierunkowanie sugestii zawartej w tym pytaniu jest oczywiste - materia, która jest z definicji martwa, należy do sfery podziemi, Ciemności. Rozpoznanie w nim zawarte zresztą Uczeń potwierdza: „Dopóki ogień pragnień surowy / na usta spada, / w nieznanych nocy senne parowy / wiedzie mnie rada". Jednakowoż, kiedy uczeń mówi: ,Tylko suchego w skroniach szelestu / krwi mojej słucham. / Oto pieśń wieczna, dopóki jestem / światłem i ruchem”, to z jednej strony potwierdza swoją przynależność poprzez ciało do materii świata, zarazem jednak, jak manichejczycy, wskazuje na dwoistość natury człowieka, która otwiera możliwość zbawienia i zwycięstwa Światłości.

Gnostycki kontekst tłumaczy także zagadkową frazę „Od światła wszystko, co żyje, umiera" z Bram arsenału, ale powracającą także w innych wierszach Trzech zim, jak choćby „okrutne światło” w Dialogu, od którego „,siły / w pył, w szarej ziemi urodzajne iły / zmienia się ciało umierając długo" (s. 26). Ta druga fraza zresztą zdaje się wyjaśniać pierwszą. Tak natomiast interpretuje ją Miłosz w rozmowie z Gorczyńską:

W tamtym okresie bardzo często śniło mi się światło, które mnie goniło i przebijało na wylot. Rodzaj śmiercionośnego promienia, laseru, od którego umierałem. [...] Co to oznaczało - nie wiem. Bo światło w moich wierszach występuje też jako przedmiot zachwytu, ekstazy, podziwu. Wszystko się przemienia w światło w sensie świetlistości, przezroczystości, w sensie przeistoczenia w jakąśs czystszą formę. To jedno. A drugie - światło okrutne, nieludzkie, które jest antyżyciem ${ }^{37}$.

Ambiwalencja ta, zaskakująca w kontekście tradycji chrześcijańskiej, wydaje się w pełni uzasadniona w świetle doktryny manichejskiej, gdzie warunkiem ostatecznego zwycięstwa Światłości, jego oddzielenia od Ciemności, jest zniszczenie tego, co z nią związane, co było efektem demiurgicznego stworzenia, a zatem życia ziemskiego, światowego. W tym sensie jest to światło „okrutne”, niszczące, zabijające życie, ale życie pozorne, przynależne materii, wiodące natomiast do oczyszczenia, do życia prawdziwego, duchowego.

Najsilniej chyba w gnostycyzmie zakorzeniony jest Hymn. „Hymn jako zapis participation mystique..." - powiada o tym wierszu Marek Zaleski.

Wszystko w tekście zdaje się na to wskazywać. Choćby trzykrotnie powtórzone [...]: „Nikogo nie ma pomiędzy tobą a mną" - co sugeruje sytuację pozostawania w modlitewnej unii, jak i pragnienie roztopienia się w przebóstwionym świecie. To „najbardziej panteistyczny ze wszystkich moich wierszy" - zauważa Miłosz w rozmowie z Gorczyńską. Zejście w życiodajny humus,

${ }^{37}$ E. Czarnecka, op. cit., s. 28. 
grób i kolebkę (Ja, wierny syn czarnoziemu, powrócę do czarnoziemu) i zapowiedziany powrót „W wiecznych wód obszary”, niczym w micie wiecznego powrotu rysują perspektywę istnienia kosmicznego; są tylko zmianą szczebla i postaci egzystencji ${ }^{38}$.

W rozmowie z Gorczyńską sytuuje jednak Miłosz Hymn także w tradycji gnostyckiej. Kluczowa wydaje się deprecjacja materii, łudzącej powabem świata, a jednocześnie odsłaniającej swoją drugą, negatywną stronę:

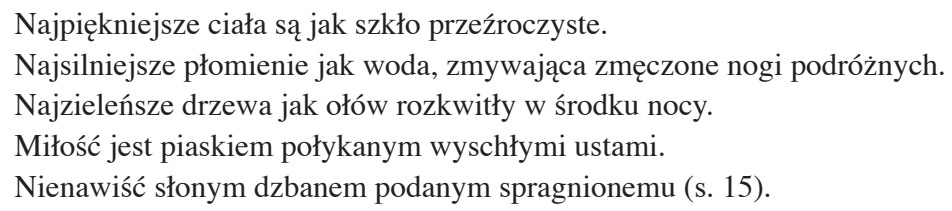

Każda z przywołanych rzeczy, kuszących pięknem, siłą, zielenią czy przywołanych afektów, ujawnia negatywną ,podszewkę" - związek ze złymi mocami, co uzasadnia zastosowanie zasady coincidentia oppositorum, o której wspomina Zaleski, a stanowi też propozycję interpretacji wersów uznanych przez niego za zdania „o niejasnej treści”. Konstatacji znikomości wszystkiego, co należy do życia światowego, towarzyszy w Hymnie akcentowanie przynależności człowieka do materii. Tak bowiem można interpretować słowa: „Ja, wierny syn czarnoziemu, powrócę do czarnoziemu", szczególnie w zestawieniu z następującym po nich inwokacyjnym: „O ciemności / [...] / Ileż razy z tobą płynąłem / zatrzymany pośrodku nocy” oraz z konstatacją podobieństwa ,ja” podmiotu i ciemności: „a my byliśmy podobni: / jabłka, nożyce, ciemność i ja” (s. 16).

Pojawia się w Hymnie także zapowiedź rozdzielenia tego, co zostało zmieszane: ,przemieniają się formy, rozpada się to, co wydawało się niezwyciężone”. Stanowi to zapowiedź nadejścia Trzeciego Czasu w bliżej nieokreślonej przyszłości (,Jeszcze nie odzywa się głos rogu / zwołujący rozproszonych, leżących w dolinach”). Ostatnie zdanie Hymnu: „Pomiędzy mną i tobą nie ma nikogo” powraca trzykrotnie, jakkolwiek w zmienionej postaci: jako rozpoczynające pierwszą i drugą strofoidę odwraca relacje zapisane w zdaniu kończącym Hymn: „Nikogo nie ma pomiędzy tobą i mną". Dodatkowo początkowa rozwija tę frazę: „Nikogo nie ma pomiędzy tobą i mną. / Ani rośliny czerpiącej sok z głębokości ziemi, / ani zwierzęcia, ani człowieka, / ani wiatru chodzącego pomiędzy chmurami", co do pewnego stopnia przypomina fragment manichejskiego hymnu: „Każdego dnia coraz mniejsza / liczba dusz [na ziemi] / podczas gdy oczyszczone zmierzają ku górze" ${ }^{39}$. Do pewnego jednak, manichejski hymn bowiem przedstawia ostani etap, eschatologiczny, ponownego oddzielenia Światła od Ciemności i oczyszczenia duszy. Hymn Miłosza buduje zaś sytuację swego

\footnotetext{
${ }^{38}$ M. Zale ski, Zamiast. O twórczości Czesława Miłosza, Kraków 2005, s. 123.

${ }^{39}$ Cyt. za H. Jon as, op. cit., s. 248.
} 
rodzaju intymnego kontaktu z Bogiem, w którym raz określa relację między Bogiem a człowiekiem (,,pomiędzy tobą i mną nie ma nikogo”), drugi raz odwrotnie: między człowiekiem a Bogiem (,pomiędzy mną i tobą nie ma nikogo”). Zastanawia jednak wyznanie:

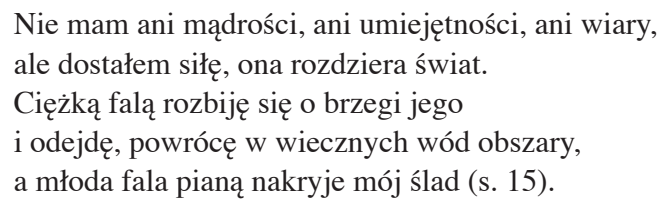

Znaczące, iż po tym wyznaniu następuje wspomniana inwokacja do ciemności. Niepokoją także atrybuty przypisane Bogu; i one nie pozwalają przyjąć, iż jest to Bóg Starego czy Nowego Testamentu:

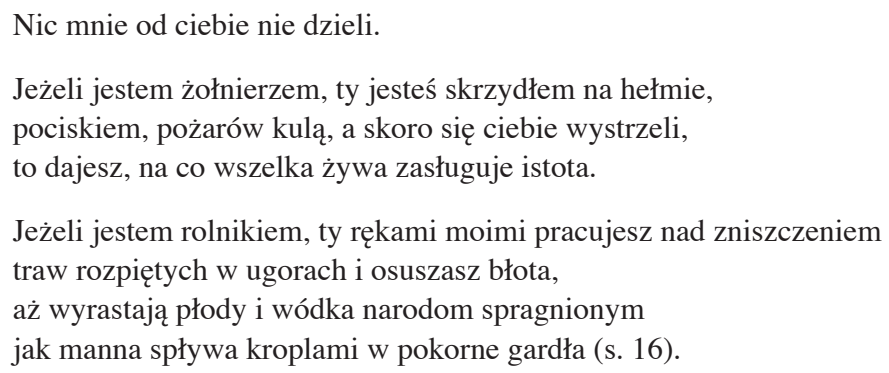

Stwierdzenie: „Nic mnie od ciebie nie dzieli” jest zatem poświadczeniem tożsamej natury Boga, tu jako gnostyckiego Demiurga, i człowieka, ich dyspozycji do sprawstwa zła? Dlatego młodość „czysta jak słoneczny kurz, / ani w dobrem, ani w złem nie rozmiłowana” okazuje się ,pod twoje olbrzymie nogi podesłana, / abyś ją gniótł, abyś po niej szedł, / abyś poruszał swoim oddechem koło, / a od jego ruchu drżała znikoma budowla, / abyś jej głód, a innym dawał sól, wino i chleb". To nie jest bóg miłosierny, odwrotnie - karzący, a raczej niszczący rękoma swojego stworzenia, co jest tradycyjnym atrybutem Lucyfera. W takim wariancie zbliża się do Boga ,prawodawcy”, wielokrotnie powracającego w twórczości Wata. Jak pisze Jonas:

Wszechświat, domena Archontów, przypomina ogromne więzienie, którego najgłębszy loch stanowi Ziemia, widownia ludzkiego życia. [...] Od strony fizykalnej panowanie to [Archontów] wyraża się w prawie natury; w swym aspekcie psychicznym, który obejmuje na przykład ustanowienie i narzucenie mojżeszowego Prawa, ma ono na celu zniewolenie człowieka ${ }^{40}$.

Istotna wydaje się tu także dodatkowa uwaga Jonasa. Archontów w niektórych gnostyckich koncepcjach, m.in. manichejskiej, zastępuje ich przywódca,

${ }^{40}$ Ibidem, s. 59. 
Demiurg, ,przedstawiany często przy pomocy zniekształconych cech Boga Starego Testamentu"41. Tak niewątpliwie jest w Hymnie Miłosza. Jeszcze wyraźniej rysuje się to w wierszu Wata Policjant. Struktura tego wiersza opiera się na metaforycznym złączeniu dwóch figur: policjanta-człowieka i Policjanta-Boga, w efekcie obaj zyskują cechy przeciwstawnych członów - Bóg występuje w roli policjanta, policjant w roli Boga, co aktualizuje gnostycką metaforę świata-więzienia. Tytułowemu Policjantowi przypisana zostaje rola strażnika prawa ludzkiego (,,brzęczy mu pierś orderami / w rękach dzwonią kajdanki”), zarazem jednak jawi się on jako władający prawem kosmicznym Bóg (,„o on był! co śmigłą gumą / świat do obrotu podcinał / nad światem nieba pergamin / jak rolkę praw swych rozwinął", s. 162-163).

Bóg jest tu ponad wszelką wątpliwość gnostyckim Demiurgiem, stwórcą kosmosu, natury i świata ludzkiego. Jego dziełem jest też prawo, stronice prawa tego okazują się jednak puste, bowiem dyktowane są przez Demiurga w celu władania ludzkim światem, Boga, który ,syna własnego na krzyżu / rozpiął za prawa zniewagę". Syn to oczywiście Jezus, który przeciwstawił się Prawu mojżeszowemu, jawi się zatem jako jeden z wielu gnostyckich buntowników wobec prawa demiurgicznego, wśród których obok Jezusa znaleźli się Kain, Adam, Set. W wierszu to Bóg-stwórca, gnostycki Demiurg pilnuje świata, kierując się Prawem mojżeszowym, o którym gnostyk Justyn mówi: ,„prawo mojżeszowe nie jest prawem pochodzącym od najwyższego Boga"42. I to właśnie temu Bogu Prawa sprzeciwił się Jezus, podejmując misję skierowaną do Adama. Quispel podaje: „W Apokryfie Jana zapisano, że Chrystus skłonił pierwszego człowieka do nieposłuszeństwa nakazom Stwórcy i zjedzenia owocu z drzewa wiadomości dobrego i złego" 43 . I za to w interpretacji Wata został ukarany ${ }^{44}$. W systemie manichejskim następuje bowiem swego rodzaju rozszczepienie Jezusa-Chrystusa na dwie istoty, w którym Jezus jest ,personifikacją całego Światła zmieszanego z materią; to znaczy jest on formą Praczłowieka przeżywającego cierpienie" ${ }^{45}$. Jako taki, dzieli z człowiekiem jego los i go utwierdza. „Wiekuisty Chrystus niebiański” pełni rolę wybawicielską - staje się przewodnikiem człowieka w drodze do przebudzenia ze snu, do zmartwychwstania w duchu w Trzecim Czasie ${ }^{46}$. Pogłos takiego przeświadczenia zdaje się pobrzmiewać w wierszu Miłosza Ptaki:

Dziecko, niedobre dziecko, czemu nas budziłeś, my byśmy, powiązani skrzydłami w kolisko,

41 Ibidem.

${ }^{42}$ K. Rudolph,op. cit., s. 151.

43 G. Qu is pe 1, Gnoza, przeł. B. Kita, Warszawa 1988, s. 87.

44 Na gnostycki kontekst tego motywu zwraca uwagę także Venclova: ,przeciwstawienie: Jehowa - Chrystus (ofiara), zawiera akcent gnostyczny i kojarzy się z Mopsożelaznym piecykiem" - Aleksander Wat-obrazoburca, s. 116.

45 H. J o nas, op. cit., s. 243.

46 K. Rudolph,op. cit., s. 154. 
drzemali aż do chwili, kiedy On rozdzieli

ciebie i nas, ubogi czas i wielkie wszystko (s. 8).

Manichejskie ujęcie Jezusa-Chrystusa do pewnego stopnia wyjaśnia też zagadkowe obrazy Watowego wiersza o incipicie „Śpiewały chórem obłoki...”, przywołanego wcześniej. „Antychryst” rozpięty na krzyżu i wzywający Lucyfera, który musiałby w tym wypadku zostać utożsamiony z Lucyferem-buntownikiem (w przeciwieństwie do Arymana „,czystego ducha niebytu” ${ }^{47}$ ), byłby tu cielesnym Jezusem, którego pierwotna misja nie powiodła się, który jednak zapowiada wybawicielską rolę Chrystusa Świetlistego. W tym kontekście tłumaczyłaby się przemiana „w boku krwi” wina w wodę, zyskującą określenia sugerujące „niebiańskość” („niebiański trunek”, który „niebieskim strumieniem się leje, dźwięczną fisharmonią"). To zapowiedź odrodzenia i misji Chrystusa, odsuniętych jednak w nieokreśloną przyszłość. Trzecia Epoka jeszcze nie nadeszła - ukrzyżowanego „przebija włócznią” noc. Wiersz zamyka wizja zwycięstwa Ciemności - „czarnej messy”, lucyferycznej, dowodzącej niepowodzenia misji Jezusa:

Żar bił od żarna nocy, wrzask od westchnień i jęków.

Zgrzytanie zębów, i wycie, i lament, i płacz udręki.

I w dźwiękach tych straszliwych o jakże czarnej messy

wracamy z morza ongi w morzu topione biesy.

A kiedy dzień nad nami wzniesie swój krwawy tasak, ryje nasze w gorący znów zaryjemy piasek.

Nawet jeśli uznać zaproponowaną interpretację, uspójniającą ten niejasny wiersz, za słabą hipotezę, bo miał on być przede wszystkim obrazoburczą prowokacją, to jej kierunek wydaje się znaczący.

Wiersz Wata Policjant kończy się eksklamacją: „lecz ja wiecznie głodny rzeknę po prostu / com widział w duchu, choćby mnie okuł: / że bliski dzień gdy zniknie jak krosta / policjant z góry, policjant z rogu", co stanowi zapowiedź nadejścia gnostyckiego Trzeciego Czasu. „Wody żywej”, zapowiedzi gnozy, szuka uczeń w Ptakach Miłosza. Pokrewnym motywem jest powstanie i biegnięcie w obliczu „ognia świata” w Rokach, a także w innych wierszach „wezwanie” $\mathrm{i}$,odpowiedź”. W tradycję gnostycką wpisane jest bowiem przeświadczenie, iż człowiek nie może ,sam się wyzwolić ze swego więzienia. Jest nie tylko zamknięty, ale i «śpi» czy też «upił się». Dopiero «wezwanie», dochodzace z zewnątrz, może go «obudzić» czy «otrzeźwić». [...] Chodzi o przebudzenie «nasienia światła» w myśli człowieka"48. Znaczące okazuje się w tej perspektywie

${ }^{47}$ T. Ven clova, Aleksander Wat-obrazoburca, s. 162.

${ }^{48}$ K. Rudolph,op. cit., s. 131. 
Watowe ,widzenie w duchu”, a zatem odwołanie do tego składnika natury ludzkiej i tej władzy człowieka.

Jak pisze Venclova, motywy integrujące tekst Piecyka nawiązują do ,religijnych archetypów i/lub gnostycznej mitologii jaźni" ${ }^{49}$. Sens wędrówki podmiotu jawi się przeto jako historia poszukiwania tożsamości w ,świecie cieni”, który nie jest ,prawdziwą ojczyzną człowieka" ${ }^{50}$. Cel tej wędrówki okazuje się jednak niespełniony, a pełna gnoza niedostępna. I dla Miłosza warunkiem oczyszczenia (,,i staną w blasku jakiejś jednej chwili / wiosna i niebo, i morza, i ziemie" w Powolnej rzece) jest ożywienie ,prawdy wielkiej”. Nie może ona być związana z poznaniem zmysłowym, ponieważ jako zależna od cielesności człowieka, pozostaje w sferze snu, ciemności, martwoty, co prowadzi obu poetów w stronę pewnego mistycyzmu. O, gnostyckim” Piecyku Wata pisze Venclova:

Poemat Wata jest tyleż porywem mistycyzmu, co zaprzeczeniem wartości mistycznego poznania. Bo jeśli, jak chcieli gnostycy i kabaliści (a także romantycy i symboliści) świat je st Księgą, to Księga nie może być rozszyfrowana. Nieznany nadawca - jeśli istnieje - wysyła przypadkowe sygnały. Może nawet jest to sam Szatan, który kusi i zwodzi nas bezsensownymi odpryskami Drzewa Wiadomości ${ }^{51}$.

Konstatacja ta zdaje się być w pełni prawomocna także w przypadku Miłosza. W gnozie zapewne pociagał obu tkwiący w niej czynnik polemiczny wobec kultury opartej na tradycji katolickiej, udzielającej niedostatecznej odpowiedzi na kryzys teodycei, na pytanie: unde malum? Dlatego z systemu filozoficzno-religijnego gnostycyzmu wyciągają przede wszystkim ,ciemne esencje” i wybiórczo symbolikę. Tłumaczy to „obrazoburstwo”, w pewnym sensie wpisane w doktrynę gnostycką, często polemicznie reinterpretującą teksty starotestamentowe. Przede wszystkim jednak dowodzi pewnego ukierunkowania katastroficznej wyobraźni.

49 T. Venclova, Gnostyczny „Piecyk” Aleksandra Wata, s. 60. Pisze Venclova: „Według doktryny gnostycznej «ja» empiryczne, podmiot pogrążony w świecie «ziemskiego snu», w różnorodności, która równa się nieistnieniu, może powrócić do swej prawdziwej ojczyzny, «przekroczyć» pirincipium individuationis tylko odnalazłszy swe prawdziwe «ja» - poprzez spotkanie swego niebiańskiego odpowiednika" (s. 70).

${ }^{50}$ Ibidem, s. 69.

${ }^{51}$ Ibidem, s. 55. 


\title{
Barbara Sienkiewicz
}

\section{GNOSTIC THOUGHT AND GNOSTIC SYMBOLISM IN THE EARLY POETRY OF ALEKSANDER WAT AND CZESŁAW MIŁOSZ}

\begin{abstract}
Summary
The interwar verse of Aleksander Wat and Czesław Miłosz provides us with ample proof that both poets came to share a pessimism about the future course of European civilization. That belief led them both to develop a sympathy with the political left and, at the same time, an interest in religion. The shift to the left, however, was arrested as soon it became clear to them that this worldview offered no solution to the problem of evil in the world. Nor were they satisfied with the traditional answer to the question unde malum? that could be found in European culture rooted in its Catholic heritage. Having reached that point both poets turned to Gnosticism, a system of thought to which the problem of metaphysical evil is absolutely central. It is that philosophy and its rich symbolism that supplied them with a number of motifs to express their vision of the decline and fall of civilization.

The article traces and analyzes the Gnostic ideas, motifs, images and symbols that express and give shape to the pessimistic vision of both Wat and Miłosz. It also argues that their 'iconoclastic' attitude which manifests itself among others in polemical reinterpretations of Old Testament texts is a consequence of their fascination with the Gnostic worldview.
\end{abstract}

